\title{
Engagement and Satisfaction of Senior High School Teachers and Students during the Emergency Remote Teaching (ERT)
}

\author{
Juland Dayo Salayo ${ }^{1}{ }^{*}$, Jann Ernest Fesalbon ${ }^{1}$, Lorena C. Valerio ${ }^{1}$, Icvalerio \\ Rodrigo A. Litao 1,2,3 \\ ${ }^{1,}$ Senior High School, University of Santo, Manila 1015, Philippines \\ ${ }^{2}$ Faculty of Arts and Letters, Department of English, University of Santo Tomas, Manila 1015, Philippines \\ ${ }^{3}$ Graduate School, University of Santo Tomas, Manila 1015, Philippines
}

\begin{tabular}{lll}
\hline Received: 21.03.2021 & • Accepted: 08.04.2021 & Published: 30.06.2021 \\
\hline
\end{tabular}

\begin{abstract}
This quantitative study aims to determine teachers' and students' perceptions of engagement and satisfaction during emergency remote teaching (ERT), together with the significant differences of the variables on the teachers' profiles. Participated by 147 and 409 senior high school teachers and students in a comprehensive Catholic university, it was revealed that the respondents have positively engaged in different virtual lessons and activities. This affirmative participation also gives way to construct online satisfaction among teachers despite few identified circumstances like the students' poor confidence in their learning, the benefits of online teaching and instructional materials, and school authorities' support. Still, teachers' and students' engagement and satisfaction remain different. In contrast, teachers' profiles like strand and year in service appear significant to teachers' satisfaction, while age and educational attainment appear significant for both teachers' engagement and satisfaction. Results further prove that the quality of engagement in a virtual learning environment remains a significant academic issue during the COVID-19 pandemic to achieve pedagogical and learning success. Hence, similar studies on engagement and satisfaction with virtual learning may be conducted using comprehensive tools and methods for a different set of respondents to assess quality instructions and to achieve learning equity.
\end{abstract}

Keywords: online engagements, online satisfaction, emergency remote teaching (ERT), senior high school, Catholic university

\section{Introduction}

Learning engagement is usually associated with the participation or involvement of learners in the learning process. However, with the shift of learning platforms from traditional to an online environment, communication between the teachers and students is immensely affected, which further produced poor learning proficiency, satisfaction and some schools are not yet ready for distance learning schemes (Asio \& Bayucca, 2021; Hu \&Li,2017). With the declaration of COVID-19 as a world pandemic, educational institutions have compelled a revolutionary shift of instructions using e-learning modality. This move has allowed various virtual instructional approaches like blended learning and distance learning that sustain students' engagement and collaboration. Hence, learners still demonstrate satisfaction, motivation, and performance to become autonomous learners [1].

\footnotetext{
* Corresponding Author: Juland D. Salayo (jdsalayo@ust.edu.ph)
} 
While several studies on engagement $[10,13,17]$ and satisfaction $[4,21]$ were already initiated, it is observed that there are only a few academic studies have investigated the level of satisfaction in an online learning territory specifically concentrated on $\mathrm{K}$ to 12 programs [6] especially during the remote emergency teaching (ERT).

\subsection{Engagement}

A study conducted proved that students' engagement is an essential element in an online environment, so the researchers deem it necessary to assess and validate the student's active participation in such a different environment using self-reported engagement. The findings show that the application behaviors and observation learnings are positively related; only the former are significantly correlated with the self-reported engagement. Observation of learning activities is less effective if they are not viewed, answered, commented, and discussed with them. In the interaction between the teachers and learners regarding the contents, online learning equates with actual learnings in the classroom; thus, these findings endorse social constructivism, which supports application learning behaviors, and not so much observation learning activities [7].

It was also expressed in another research that the engagement of the learner is an integral part of students' education. The study shows that teacher educators must have different teaching strategies depending on the needs of the learners. Teachers should make their curriculum more engaging so that transferring knowledge and skills to the learners becomes easy. It was also noted for the educators to work together with the other members of the learning community to develop strategies to encourage students to engage in online activities [19].

A group of researchers set up a hybrid learning virtual classroom to know the extent of relatedness, the intrinsic motivation, and learning achievement of students in different learning settings and found that students' engagement is relatively low in the hybrid settings. The students' relatedness to teachers and peers affects students' intrinsic motivation, hence affecting the quizzes given to them. Although their intrinsic motivation decreases during hybrid virtual learning, intrinsic motivation improves when taking their quizzes. The synchronous learning space is good due to its flexibility which can introduce the students into a more expansive and different perspective views and ideas. It appears challenging for the teachers, but in this study, the teaching style was not affected as teachers could still create a dialogue with their students as they used to do [15].

In another significant study, the findings revealed essential factors for the successful engagement of students in an online learning environment, as follows: formal and informal community, time management and organizational skills, engaging and supportive online teachers, multiple means of interaction, not just forums, and opportunities for skill development, confidence building, and selfregulation. The capacity of the learners to balance studies with other responsibilities affects their performance in online activities. It also appears that asynchronous or synchronous forums did not precisely comply with the students' needs and that despite creating group works online, it does not remove the feeling of isolation and separation from their peer groups. Confidence, time management, and organizational skills play a significant part in online learning success, but it is essential to note that the teacher who guides, moderates, and supports the learners occupies the highest rank contributing to the learners' success online [8]. 


\subsection{Satisfaction}

Satisfaction toward online teaching and learning is linked to both students and teachers. Accordingly, student satisfaction is the learners' perception of their engagement to different educational activities in any academic venue, and even if other factors affect that satisfaction level, it remains the most significant indicator to sustain learning. Various factors that shape learners' satisfaction were discussed; these include "instructor, technology, interactivity ... communication, course management issues, course websites; self-efficacy, social ability, quality of system and multimedia instructions" (105). In contrast, other elements serve as barriers to online learning satisfaction like "administrative issues, social interaction, motivation, time, limited access to resources, technical difficulties, unfamiliar roles and responsibilities, delays in feedbacks from instructors, limited technical assistance, high degrees of technology dependence, and low student performance and satisfaction" (p. 105). On the part of the teachers, satisfaction appears to be multifarious because of the associated complex factors like their lifestyle, demographics, motivation, and work condition; hence, their satisfaction is also a perception in the effectiveness and constructiveness of their duty in online teaching, which are attributed associated to students, instructors and institutional-related aspects [4].

Looking into these three identified factors that construct teachers' satisfaction, it was proven that the university faculty's satisfaction in an online teaching is undoubtedly influenced by several factors associated with their student, fellow teachers, and their institution. Using an online faculty satisfaction survey (OFSS) further proves that teachers promote student-centeredness in their online instructions as the learners appear to be the most influential factor why they have a positive engagement to remote teaching. In this study, student-centeredness is manifested by students' flexibility and convenience in their access to online courses and active communication with their teachers. On the part of instructors-related issues, this study proved that teachers still need to improve their creativity in online teaching, while institutional-related issues highlighted their impact on teachers' motivation [4].

Applying both survey and interview, several factors were identified that shaped teachers' high level of their overall satisfaction, which are manifested in the following features and implications of online instructions: flexibility in terms of time, place, and manner of online teaching, individual approaches which address specific needs of the learners, observed positive implications to the overall learning performance of their students and administrative support and appreciation to them. Hence, the overall manifestation of the respondents' satisfaction was shaped by flexibility in their instructions, communication with their students, and community support specifically attributed to the administration [6].

Guided by motivational needs theory and social presence theory to measure learners' perceptions toward virtual territory, social presence, and satisfaction, a study found out that virtual environment has shown a correlation with social presence while these variables have proven their significant effects on the learner's level of satisfaction toward e-learning modality. Such results were influenced by the use of social media platforms in designing and implementing classroom activities that further promote collaboration and authentic academic engagement that support the learners' interest. Applying descriptive design, this study was shaped by six significant constructs which are arranged from highest to lowest based on the scores given by the participants: "instructor support, student interaction and collaboration, student autonomy, authentic learning, personal relevance, and active learning" (p. 102). While the results show a favorable status of the student satisfaction that proves their learning autonomy, the results also revealed that the participants did not prefer this online 
learning mode with negative issues toward personal engagement and relation with others. The result is highly attributed to the "impersonal nature of the curriculum" (p. 105) [20].

A more comprehensive study on the different features of virtual teaching was examined concerning the student satisfaction using Pekrun's control-value theory of achievement emotions by to the 29 students in the graduate school with blended learning modality. The results show that the high level of student's satisfaction with online learning is greatly attributed to their positive level of understanding of the lessons and their enthusiasm for this learning modality. Interestingly, the increased level of satisfaction is notably shaped by the respondents' positive attitude such as maintaining their happiness and decreasing the negative emotions such as anger and boredom. It is vital that the online instructions, vocabulary, and activities be simple, straightforward, and studentcentered to achieve this good level of satisfaction [9]. Lastly, it was proven that most university students in their study reached an increased level of satisfaction as far as virtual courses and programs are concerned, specifically highlighted by the engagement between teachers and learners to other learners. However, results also revealed that some areas need to be attended to, including communication with the teachers, clarity of instructions, and technical support during enrolment and security of data [16].

\subsection{Theoretical Framework}

The present study employs Linda Harasim's Theory of Online Collaborative Learning (OCL), highlighting the functions of technology in producing learning platforms that promote collaboration and engagement necessary to sustain learning. With the support of the internet, online or virtual learning environment "reshapes formal, non-formal, and informal education for the Knowledge Age" (p. 175). Hence, the promotion of engagement is evident in three phases of knowledge production: (1) idea generation, which is the brainstorming stage which allows the gathering of different ideas,

(2) idea organization where the presented ideas are processed through comparison and contrasting and analysis and (3) intellectual convergence that allows the synthesis of the gathered information like producing an agreement to disagreement engagement [14].

Similarly, Deci \& Ryan's Self-Determination Theory (SDT) also works with the present study to investigate human needs to establish a well-rounded being. Explicitly focusing on three psychological aspects of development, this theory highlights human needs toward autonomy, competence, and relatedness [12]. Understanding these needs, like physical human needs, this theory also becomes a measurement of either satisfaction or deprivation of learning goals. The first one, autonomy, pertains to self-regulations of human social engagements and actions. Its specific reference to one's choice or independence also pertains to one's values as reflected in those actions, decisions, and behaviors. In online teaching, autonomy allows teachers and students to decide the modality of teaching and learning. Their choice of instructional strategies and approaches can also support in achieving teaching-learning success and satisfaction. Then, the competence that produces motivation and comfort in online teaching helps design online tasks.

Additionally, competence can stabilize the perceived difficulties or challenges of the designed activities and instructional materials, clearly set learning goals, and build strong teacher-student engagement and progress. Finally, the relatedness that pertains to humans needs to be socially involved; hence, it values community and belongingness. Hence, online teaching promotes sharing and collaborations of knowledge, experiences, and teacher-student interactions. 


\subsection{Research Objectives}

This present study aims to:

(1) determine demographic profile of the teacher-respondents in terms of sex, age, strand, years in service, and highest educational attainment;

(2) identify the level of teachers' perceptions of online teaching in terms of engagement and satisfaction;

(3) identify the level of students' perceptions of online teaching in terms of engagement and satisfaction;

(4) determine the significant differences in the teachers' engagement and satisfaction based on their profile;

(5) determine the significant difference between the level of teachers' and students' perceptions of online instructions in terms of engagement and satisfaction.

\section{METHOD}

\subsection{1. Research Design.}

The researchers used descriptive quantitative research design. A descriptive design was chosen to determine the statistical difference between teachers' perceptions of the variables under study based on their profile and teachers' and students' perceptions of their online engagements and satisfaction during the emergency remote teaching. Descriptive research was used in this study to describe the variables systematically and accurately and the profile of SHS teachers and students during the ERT.

\subsection{Population and Sampling.}

This study incorporates a non-probabilistic sampling of convenience with a total of 409-student and 147-teacher respondents from a comprehensive university. The study underwent pilot-testing before the actual data gathering to ensure internal consistency and reliability of the research instrument. The study was conducted during the strict quarantine measures due to the pandemic, and face-toface class shifted to emergency remote teaching. The researchers also interviewed thirteen from the pool of student respondents. The study maintains anonymity, willingness to participate, protection of the respondents' rights, and mutual respect.

\subsection{Instrument.}

This study developed an instrument for teacher and student respondents to assess their perceptions of their online engagements and satisfaction during emergency remote teaching. The research instrument consists of a preliminary section composed of a Data Privacy Statement, Consent Form, and Personal Background, and the questionnaire properly constituted the Engagement and Satisfaction Scale. Each respondent was asked to rate their perception of their Engagement and Satisfaction during the emergency remote teaching using 4-point Likert scale questions to capture the respondent's degree of agreement on the different statements included in each of the variables under study. The instrument is comprised of 7 questions for engagement and 10 questions for the satisfaction scale. The research instrument utilized a four-point Likert scale with an increasing degree of agreement: 1 - Strongly Disagree, 2 - Disagree, 3 - Agree, and 4 - Strongly Agree. A 
pilot test was conducted on 36 teachers and 39 students; the data were analyzed using Cronbach's Alpha. The Reliability Statistics was carried out using SPSS v.23, where the results show high and acceptable reliability in the scales in both teacher and student research instruments. The research instrument for teacher participants has a good internal consistency $(0.9>\alpha>0.8)$ with Cronbach's Alpha of 0.894 (0.849-Engagement, and 0.939-Satisfaction). On the other hand, the research instrument for student participants has an acceptable internal consistency $(0.8>\alpha>0.7)$ with Cronbach's Alpha of 0.750 (0.709-Engagement, and 0.791-Satisfaction). Results in the Engagement and Satisfaction scale were interpreted using a range: 1.00-1.75 Strongly Disagree; 1.76-2.50 Disagree; 2.51-3.25 Agree; and 3.26-4.00 Strongly Agree. The target respondents accessed the instrument thru a link provided to them by the researchers. Included in the online research instrument are the data privacy statement and informed consent form.

\subsection{Data Gathering and Analysis.}

A permission letter was sent to the Senior High School Department administrator of a comprehensive Catholic university for approval to conduct and gather data from their SHS students and faculty members. After the approval was secured, the researchers communicated to the strand chairs and subject area lead teachers to encourage and send the link of the research instrument to all the teachers under their supervision, and the class advisers sending the link of the instrument to their respective advisory class. The data was downloaded as an Excel file generated by the online form. Data were treated, tabulated, and analyzed to provide sound interpretation as a response to the research questions posted in this study. Frequency distribution, percentage, mean, and ANOVA (Analysis of Variance) were used utilizing IBM SPSS v.23 to carry out the statistical tests needed in the study.

\section{RESULTS AND DISCUSSION}

\subsection{1. Respondents' Demographic Profile}

The study was participated by 409 students and 147 teachers of the Senior High School Department in a comprehensive Catholic university in Manila. The study was conducted during the strict quarantine measures amidst a pandemic where learning and instruction are suddenly shifted from conventional face-to-face classes to emergency remote teaching. The succeeding tables below present the profile distribution of the respondents of this study.

Table 1. Profile Distribution of Student-Respondents

\begin{tabular}{lll}
\hline & Frequency & Percentage $(\%)$ \\
\hline Gender & & \\
Male & 140 & 34.23 \\
Female & 269 & 65.77 \\
\hline Age & & \\
16 years old & 51 & 12.47 \\
17 years old & 214 & 52.32 \\
18 years old & 123 & 30.07 \\
19 years old & 21 & 5.13 \\
\hline Grade Level & & \\
Grade 11 & 270 & 66.01 \\
Grade 12 & 139 & 33.99 \\
\hline
\end{tabular}




$\begin{array}{lll}\text { Strand } & & \\ \text { STEM (Science, Technology, Engineering \& Mathematics) } & 118 & 28.85 \\ \text { ABM (Accountancy, Business \& Management) } & 64 & 15.65 \\ \text { HA (Health Allied) } & 104 & 25.43 \\ \text { HUMSS (Humanities and Social Science) } & 74 & 18.09 \\ \text { PES (Physical Education and Sports) } & 19 & 4.65 \\ \text { MAD (Music, Arts, and Design) } & 30 & 7.33\end{array}$
$\mathrm{n}=409$

In this study, more female students participated, with $65.77 \%$ than $34.23 \%$ of male students who responded during the conduct and actual data gathering. Student respondents have an average age of 17.28 years wherein $52.32 \%$ or 214 were 17 years of age, $30.07 \%$ (123) of students age 18 years old, while there are only $51(12.47 \%)$ who were 16 and 21 (5.13) 19-year-old respondents. Both grade levels of Senior High School were represented in this study with $270(66.01 \%)$ Grade 11 and 139 (33.99\%) Grade 12. STEM or Science, Technology, Engineering \& Mathematics, and HA or Health Allied strands have the highest number of student respondents who participated in the study with 188 (28.85\%) and 104 (25.43\%), respectively. While, MAD or Music, Arts, and Design and PES or Physical Education and Sports have the lowest number of participating students, 30 (7.33\%) and 19 (4.65\%), respectively.

This study also requested the participation of SHS faculty members from across strands and learning areas of the department. Information such as gender, age, strand affiliation, years in service, and highest educational attainment were gathered from the 147 teacher respondents.

Table 2. Profile Distribution of Teacher-Respondents

\begin{tabular}{lll}
\hline & Frequency & Percentage $(\%)$ \\
\hline Gender & & 49.66 \\
Male & 73 & 50.34 \\
Female & & \\
\hline Age & 63 & 42.86 \\
20-29 years old & 36 & 24.49 \\
$30-39$ years old & 31 & 21.09 \\
$40-49$ years old & 17 & 11.56 \\
50-59 years old & & \\
\hline Strand Affiliation & 9 & 6.12 \\
STEM (Science, Technology, Engineering \& Mathematics) & 25 & 17.01 \\
ABM (Accountancy, Business \& Management) & 14 & 9.52 \\
HA (Health Allied) & 22 & 14.97 \\
HUMSS (Humanities and Social Science) & 6 & 4.08 \\
PES (Physical Education and Sports) & 6 & 4.08 \\
MAD (Music, Arts, and Design) & 65 & 44.22 \\
Specific Learning Areas & & \\
\hline Years in Service & 78 & 53.06 \\
3 years \& below & 47 & 31.97 \\
4 to 10 years & 17 & 11.56 \\
11 to 20 years & 5 & 3.40 \\
More than 20 years & & \\
\hline Highest Educational Attainment & 47 & 31.97 \\
Bachelor's & 94 & 63.95 \\
Masters & 6.08 \\
Doctorate & & \\
\hline
\end{tabular}

$\mathrm{n}=147$ 
This study was well-represented by SHS faculty members in a comprehensive university where 73 (49.66\%) males; and 74 (50.34\%) female teachers responded voluntarily; hence, a good combination of young and seasoned faculty members was observed with 63 (42.86\%) of 20-29 years old age group who had the most number of participants, 36 (24.49\%) from 30-39 year old, 31 (21.09\%) from 40-49 years old, and 17 (11.56\%) from 50-59 years old age group. Nearly half or 65 (44.22\%) of the teacher respondents were from Specific Learning Areas comprised of Personality Development, Philosophy, English, and alike - courses taught to all the strands. On the other hand, there are also SHS teachers who responded in the study representing the different strands/clusters such as STEM (Science, Technology, Engineering \& Mathematics), PES (Physical Education and Sports), and MAD (Music, Arts, and Design) which have the least number of respondents with 9 (6.12\%) while PES and MAD have $6(4.08 \%)$ respectively. In terms of the respondents' educational background, the student was dominantly participated by $78(53.06 \%)$ SHS teachers who are 3 years and less in the service, $47(31.97 \%)$ were in their 4 to 10 years of service, $17(11.56 \%)$ were in their 11 to 20 years, and $5(3.40 \%)$ teaching for more than 20 years. As the university is encouraging and requiring teachers to pursue further or graduate studies, more than half or $94(63.95 \%)$ of the teacher respondents were also at least a master's degree holder, $6(4.08 \%)$ have a Doctorate while 47 (31.97\%) have bachelor's degree and those who are currently taking and finishing their masters.

\subsection{Teachers' Perception on Online Teaching (Engagement \& Satisfaction)}

Table 2. Teachers' Engagement on Online Teaching

\begin{tabular}{lll}
\hline Statements & Mean & Interpretation \\
\hline $\begin{array}{l}\text { I communicated actively with the students to increase teacher } \\
\text { presence in the course. }\end{array}$ & 3.56 & Strongly Agree \\
\hline $\begin{array}{l}\text { I provided feedback about the submitted output using different } \\
\text { methods (e.g., text, chat, video conferencing, and visuals). }\end{array}$ & 3.54 & Strongly Agree \\
\hline $\begin{array}{l}\text { I uploaded essential materials like PowerPoint, recorded lectures, } \\
\text { videos, supplemental readings, and alike. }\end{array}$ & 3.72 & Strongly Agree \\
\hline $\begin{array}{l}\text { I gave an opportunity to students to rate the individual performance } \\
\text { of their members on projects. }\end{array}$ & 3.23 & Agree \\
\hline $\begin{array}{l}\text { I provided scoring guidelines and grading rubrics for all outputs/ } \\
\text { tasks. }\end{array}$ & 3.71 & Strongly Agree \\
\hline $\begin{array}{l}\text { I used different learning management system's features in } \\
\text { facilitating synchronous and asynchronous sessions (e.g., polls, } \\
\text { emoticons, whiteboard, text, or group chats and video chat). }\end{array}$ & 3.46 & Strongly Agree \\
\hline $\begin{array}{l}\text { I motivate students to participate in synchronous/ asynchronous } \\
\text { discussions. }\end{array}$ & 3.66 & Strongly Agree \\
\hline \begin{tabular}{l} 
Overall Mean \\
\hline
\end{tabular} & 3.55 & Strongly Agree \\
\hline
\end{tabular}

In the engagement scale, teacher-respondents demonstrate active commitment to making their presence felt by the students even if they can only be seen through monitors. Most of the statements were rated highly, showing the teachers' engagement to their online teaching classes. Statements such as consistently uploading and providing essential materials for their classes (3.72, Strongly Agree), providing guidelines, and scoring rubrics (3.71, Strongly Agree), and motivating the students to join their sessions to maintain social interaction even without physically present in a single room (3.66, Strongly Agree) were the three highest mean scores in the engagement scale. Moreover, the 
results show that teachers were motivated to make their influence flows in different aspects of the teaching and learning process through constant communication, providing feedback for the students, and using the different features of the learning management system to facilitate interaction during synchronous and asynchronous sessions. Among the statements, only one was rated below the range showing a substantial agreement where students were occasionally allowed to participate in peer evaluation (3.23, Agree). Peer Evaluation might be rated lower than the rest of the statements in the engagement scale may be due to the applicability to the type of assessments given to students. Attending to the teachers' online presence, it was stated that such engagement contributes to defining their teaching profession, especially in the advancement of their classroom practices; hence, learners' motivation and learning quality are also built [5].

Table 3. Teachers' Satisfaction on Online Teaching

\begin{tabular}{lll}
\hline Statements & Mean & Interpretation \\
\hline $\begin{array}{l}\text { I felt satisfied with the contents of the instructional materials I have } \\
\text { provided online. }\end{array}$ & 3.24 & Agree \\
\hline $\begin{array}{l}\text { I felt satisfied with the length of time I have provided for the } \\
\text { students to complete the assessment tasks. }\end{array}$ & 3.42 & Strongly Agree \\
\hline $\begin{array}{l}\text { I felt satisfied with the school authorities' support to carry out the } \\
\text { sudden shift to remote instruction. }\end{array}$ & 3.41 & Strongly Agree \\
\hline $\begin{array}{l}\text { I felt satisfied with the institution's guidelines and the } \\
\text { local/academic unit regarding the desired conduct of remote } \\
\text { instruction. }\end{array}$ & 3.33 & Strongly Agree \\
\hline $\begin{array}{l}\text { I felt satisfied with my promptness and quality of assistance I have } \\
\text { extended to address students' queries and other online learning } \\
\text { difficulties. }\end{array}$ & 3.50 & Strongly Agree \\
\hline $\begin{array}{l}\text { I felt satisfied to have extended assistance to fellow faculty with } \\
\text { struggles in carrying out remote instruction. }\end{array}$ & 3.45 & Strongly Agree \\
$\begin{array}{l}\text { I felt satisfied with the benefits this emergency remote instruction } \\
\text { may have caused. }\end{array}$ & 3.22 & Agree \\
\hline $\begin{array}{l}\text { I felt satisfied with my own learnings from this emergency remote } \\
\text { instruction. }\end{array}$ & 3.37 & Strongly Agree \\
\hline $\begin{array}{l}\text { I felt satisfied with the support I have extended to the institutional } \\
\text { and local administrators to make this emergency remote instruction } \\
\text { a success. }\end{array}$ & 3.37 & Strongly Agree \\
\hline $\begin{array}{l}\text { I felt satisfied with my overall contributions to make this } \\
\text { emergency remote instruction a success. }\end{array}$ & 3.41 & Strongly Agree \\
\hline \begin{tabular}{l} 
Overall Mean \\
\hline
\end{tabular} & 3.37 & Agree \\
\hline
\end{tabular}

With the abrupt change in the conventional face-to-face classes due to the pandemic, online teaching was the solution to continue the services provided by educational institutions to their students. This study finds that teachers' respondents were generally satisfied in online teaching during the emergency remote teaching with an overall mean of 3.37, interpreted as high satisfaction. Teachers felt satisfied with their presence in assisting students' queries and learning difficulties (3.50, Strongly Agree), quality of assistance provided to colleagues (3.45, Strongly Agree), and length of time provided for the students to accomplish a task (3.42, Strongly Agree), three statements with the highest mean scores. Meanwhile, two statements were rated below the highest scale: contents of the instructional materials provided (3.24, Agree); and benefits of the emergency remote teaching (3.22, Agree). These two statements with the lowest mean score do not represent dissatisfaction; they bear a positive interpretation that teachers are still satisfied with what they offered and provided to their 
classes during the emergency remote teaching. Parallel to this study, different factors construct teachers' satisfaction in online teaching. They are highly attributed to students, instructors, and institutions [4]; likewise, administrative support helps build teachers' satisfaction, improving learners' performance [6].

\subsection{Students' Perception of Online Teaching (Engagement \& Satisfaction)}

Table 4. Students' Engagement on Online Teaching

\begin{tabular}{lll}
\hline Statements & Mean & Interpretation \\
\hline $\begin{array}{l}\text { I worked collaboratively through online conversation in chats, } \\
\text { emails, video conferences, or forums. }\end{array}$ & 3.07 & Agree \\
\hline $\begin{array}{l}\text { I reflected on the feedback about the submitted output from the } \\
\text { teacher. }\end{array}$ & 3.14 & Agree \\
\hline $\begin{array}{l}\text { I used the materials like PowerPoint, recorded lectures, videos, } \\
\text { supplemental readings, and alike provided by the teacher. }\end{array}$ & 3.40 & Strongly Agree \\
\hline $\begin{array}{l}\text { I am asked to rate the individual performance of team members on } \\
\text { projects. }\end{array}$ & 3.05 & Agree \\
$\begin{array}{l}\text { I used the guidelines and grading rubrics provided by the teacher in } \\
\text { doing my assignments/ other requirements. }\end{array}$ & 3.45 & Strongly Agree \\
\hline $\begin{array}{l}\text { I used different learning management system's features in } \\
\text { synchronous and asynchronous sessions to interact (e.g., polls, } \\
\text { emoticons, whiteboard, text, or group chats and video chat). }\end{array}$ & 3.16 & Agree \\
\hline $\begin{array}{l}\text { I am motivated to participate in synchronous/ asynchronous } \\
\text { discussions/tasks }\end{array}$ & 2.18 & Disagree \\
\hline \begin{tabular}{l} 
Overall Mean \\
\hline
\end{tabular} & 3.06 & Agree \\
\hline
\end{tabular}

One of the things that both face-to-face and online instructions would like to maintain is the engagement in the delivery of the lessons. Student respondents strongly agreed that they use varied materials (3.40, Strongly Agree), guidelines, and grading rubrics (3.45, Strongly Agree) provided by the teacher. However, students were not motivated to participate in their synchronous and asynchronous sessions (2.18, Disagree), which may be brought by the sudden change in the delivery of the lessons and the fear and uncertainties of the pandemic during the emergency remote teaching. Overall, student-respondents show engagement in online teaching through collaboration and constant communication and different learning management features to interact with classmates and teachers during learning sessions, with an overall mean of 3.06. True enough, learners' engagement is relevant even in a virtual learning environment; however, the success of their engagement is also supported by teachers' interaction and support, which include feedbacking, time management and organizational skills, confidence-building discussions and tasks, and self-regulation [7-8].

Table 6. Students' Satisfaction on Online Teaching

\begin{tabular}{lll}
\hline Statements & Mean & Interpretation \\
\hline $\begin{array}{l}\text { I felt satisfied with the contents of the instructional materials my } \\
\text { teacher provided for us online. }\end{array}$ & 2.39 & Disagree \\
\hline $\begin{array}{l}\text { I felt satisfied with the length of time my teacher provided for us to } \\
\text { complete the assessment tasks. }\end{array}$ & 2.94 & Agree \\
\hline
\end{tabular}




\begin{tabular}{lll}
\hline $\begin{array}{l}\text { I felt satisfied with the school authorities' support to carry out the } \\
\text { sudden shift to remote instruction. }\end{array}$ & 2.31 & Disagree \\
\hline $\begin{array}{l}\text { I felt satisfied with the institution's guidelines and the } \\
\text { local/academic unit regarding the desired conduct of remote } \\
\text { instruction. }\end{array}$ & 3.37 & Strongly Agree \\
\hline $\begin{array}{l}\text { I felt satisfied with promptness and quality of assistance my teacher } \\
\text { extended to us to address our queries and other online learning } \\
\text { difficulties. }\end{array}$ & 3.78 & Strongly Agree \\
\hline $\begin{array}{l}\text { I felt satisfied to have extended assistance to fellow students with } \\
\text { struggles in carrying out remote learning. }\end{array}$ & 2.95 & Agree \\
\hline $\begin{array}{l}\text { I felt satisfied with the benefits this emergency remote learning may } \\
\text { have caused. }\end{array}$ & 2.41 & Disagree \\
\hline $\begin{array}{l}\text { I felt satisfied with my own learnings from this emergency remote } \\
\text { instruction. }\end{array}$ & 2.21 & Disagree \\
\hline $\begin{array}{l}\text { I felt satisfied with the support I have extended to the institutional } \\
\text { and local administrators to make this emergency remote instruction } \\
\text { and learning a success. }\end{array}$ & 2.58 & Agree \\
\hline $\begin{array}{l}\text { I felt satisfied with my overall contributions to make this } \\
\text { emergency remote instruction and learning a success. }\end{array}$ & 2.66 & Agree \\
\hline \begin{tabular}{l} 
Overall Mean \\
\hline
\end{tabular} & 2.56 & Agree \\
\hline
\end{tabular}

The rapid shift in the delivery of the learning goals has taught the educational institution to adapt to new situations without compromising the quality of education offered to students. The study finds that students were generally satisfied with the emergency remote teaching with an overall mean of 2.56, which reflects average satisfaction during the duration of online teaching. Respondents show intense satisfaction about the academic unit's guidelines and directions and the promptness and quality of assistance extended by the teachers with a mean of 3.37 and 3.78, respectively. Satisfaction was also observed in the student perceptions but is not limited to their contributions would still make the emergency remote instruction a success, the assistance they extended to fellow students, and the teacher's length of time to accomplish a task. However, students seem not satisfied with their learning, the benefits of online teaching, contents provided as instructional materials, and the school authorities' support during the sudden shift to remote instruction with a mean of 2.41, 2.21, and 2.39, 2.31 , respectively. Similar to the results, the issue of students' satisfaction and dissatisfaction has multiple sources. While the support of the instructors, their interaction and communication, and the quality of the learning management are among those that are well credited to building satisfaction, it is also identified that barriers to entirely shaped contentment are associated with administrative matters, technical difficulties, limited access to online resources, and teachers' poor interactions and assistance [4]. The same results were observed wherein the students' perception to an educator's skills (communication, learning and innovation, information, media and technology, and life and career) got very satisfactory evaluation [2].

\subsection{Significant Differences on Teachers' Engagement and Satisfaction Based on their Profile}

ANOVA (Sex)

\begin{tabular}{|c|c|c|c|c|c|c|}
\hline & & $\begin{array}{l}\text { Sum of } \\
\text { Squares }\end{array}$ & Df & Mean Square & $\mathrm{F}$ & Sig. \\
\hline \multirow[t]{3}{*}{ ENGAGEMENT } & Between Groups & .024 & 1 & .024 & .163 & .687 \\
\hline & Within Groups & 21.048 & 145 & .145 & & \\
\hline & Total & 21.071 & 146 & & & \\
\hline SATISFACTION & Between Groups & .042 & 1 & .042 & .193 & .661 \\
\hline
\end{tabular}


30 Salayo et al., Engagement and Satisfaction of Senior High School Teachers and Students during the Emergency Remote Learning Teaching (ERT)

\begin{tabular}{llll} 
Within Groups & 31.225 & 145 & .215 \\
Total & 31.267 & 146 & \\
\hline
\end{tabular}

The study found no statistically significant difference between the teacher's engagement and satisfaction when grouped according to their gender at $\mathrm{p}<.05$. The result reveals that when grouped according to gender: teacher's engagement $[\mathrm{F}(1,145)=.163, \mathrm{p}=0.687]$; and satisfaction $[\mathrm{F}(1,145)$ $=.193, \mathrm{p}=0.661]$, though the interaction between these terms was not significant. Taken together, these results suggest that regardless of sex, teacher's engagement and satisfaction on emergency remote teaching do not have an effect or have no difference on how they perceive ERT in those specific components. Specifically, the results suggest that teacher respondents whether male or female have the same perceptions on emergency remote teaching.

\begin{tabular}{|c|c|c|c|c|c|c|}
\hline \multicolumn{7}{|c|}{ ANOVA (Age) } \\
\hline & & $\begin{array}{l}\text { Sum of } \\
\text { Squares }\end{array}$ & Df & Mean Square & $\mathrm{F}$ & Sig. \\
\hline \multirow[t]{3}{*}{ ENGAGEMENT } & Between Groups & 1.958 & 3 & .653 & 4.884 & .003 \\
\hline & Within Groups & 19.113 & 143 & .134 & & \\
\hline & Total & 21.071 & 146 & & & \\
\hline \multirow[t]{3}{*}{ SATISFACTION } & Between Groups & 3.146 & 3 & 1.049 & 5.332 & .002 \\
\hline & Within Groups & 28.121 & 143 & .197 & & \\
\hline & Total & 31.267 & 146 & & & \\
\hline
\end{tabular}

The study has a statistically significant difference between the teacher's engagement and satisfaction when grouped according to age at $\mathrm{p}<.05$. The result reveals that when clustered according to specific age groups: teachers' engagement $[\mathrm{F}(3,143)=4.884, \mathrm{p}=.003]$; and satisfaction $[F(3,143)=5.332, p=.002]$, the interaction between these terms was significant. These results suggest that teacher's engagement and satisfaction with emergency remote teaching is different from those who are in the 20-29 years old bracket than the other age groups. Specifically, the results suggest that teacher's perceptions of emergency remote teaching differ based on different age groups.

ANOVA (Strand)

\begin{tabular}{lllllll}
\hline & & \multicolumn{2}{c}{ Sum of } \\
Squares & Df & Mean Square & F & Sig. \\
\hline \multirow{2}{*}{ ENGAGEMENT } & Between Groups & 1.047 & 6 & .175 & 1.220 & .300 \\
\cline { 2 - 7 } & Within Groups & 20.024 & 140 & .143 & & \\
\cline { 2 - 7 } & Total & 21.071 & 146 & & 2.899 & .011 \\
\hline \multirow{2}{*}{ SATISFACTION } & Between Groups & 3.455 & 6 & .576 & & \\
\cline { 2 - 7 } & Within Groups & 27.811 & 140 & .199 & & \\
\cline { 2 - 7 } & Total & 31.267 & 146 & & & \\
\hline
\end{tabular}

The study found no statistically significant difference between the teacher's engagements when grouped according to the strand they belong while a significant difference is noted in satisfaction at $\mathrm{p}<.05$ level. The result reveals that when teacher respondents are grouped according to their strand: engagement $[F(6,140)=1.220, p=0.300]$ though the interaction between these terms was not significant. On the other hand, teacher's satisfaction with ERT shows a significant difference in terms of the strand they belong $[\mathrm{F}(6,140)=2.889, \mathrm{p}=.011]$. The results suggest that the strand where the teacher belongs does not have an effect or has no difference on how they perceive ERT on these 
specific components such as engagement. Specifically, the results suggest that teacher respondents from across strands and learning areas have the same perception of ERT in these specific components, such as engagement, while they have different views about the satisfaction of ERT.

ANOVA (Years in Service)

\begin{tabular}{|c|c|c|c|c|c|c|}
\hline & & $\begin{array}{l}\text { Sum of } \\
\text { Squares }\end{array}$ & Df & Mean Square & $\mathrm{F}$ & Sig. \\
\hline \multirow[t]{3}{*}{ ENGAGEMENT } & Between Groups & .469 & 3 & .156 & 1.084 & .358 \\
\hline & Within Groups & 20.603 & 143 & .144 & & \\
\hline & Total & 21.071 & 146 & & & \\
\hline \multirow[t]{3}{*}{ SATISFACTION } & Between Groups & 1.992 & 3 & .664 & 3.243 & .024 \\
\hline & Within Groups & 29.275 & 143 & .205 & & \\
\hline & Total & 31.267 & 146 & & & \\
\hline
\end{tabular}

The study found no statistically significant difference between the teacher's engagements when grouped according to their years in service, while a significant difference is noted in satisfaction at $\mathrm{p}<.05$. The result reveals that when teacher respondents are grouped according to the years, they have been teaching: engagement $[\mathrm{F}(3,143)=1.084, \mathrm{p}=0.338]$ was not significant. On the other hand, satisfaction $[\mathrm{F}(3,143)=3.243, \mathrm{p}=.024]$ on ERT shows a significant difference in the years they have been in the service as teachers. The results suggest that the years in service do not have an effect or have no difference on how teachers perceive engagement on ERT. Specifically, the results suggest that teacher respondents have the same perception of ERT, specifically on engagement, regardless of the number of years they spent as a teacher while they have different views about the satisfaction of ERT.

ANOVA (Highest Educational Attainment)

\begin{tabular}{|c|c|c|c|c|c|c|}
\hline & & $\begin{array}{l}\text { Sum of } \\
\text { Squares }\end{array}$ & Df & Mean Square & $\mathrm{F}$ & Sig. \\
\hline \multirow[t]{3}{*}{ ENGAGEMENT } & Between Groups & 1.382 & 2 & .691 & 5.055 & .008 \\
\hline & Within Groups & 19.689 & 144 & .137 & & \\
\hline & Total & 21.071 & 146 & & & \\
\hline \multirow[t]{3}{*}{ SATISFACTION } & Between Groups & 1.411 & 2 & .706 & 3.404 & .036 \\
\hline & Within Groups & 29.855 & 144 & .207 & & \\
\hline & Total & 31.267 & 146 & & & \\
\hline
\end{tabular}

The study found statistically significant difference between the teacher's engagement and satisfaction when grouped based on their educational attainment at $\mathrm{p}<.05$ level: engagement $[\mathrm{F}(2$, $144)=5.055, \mathrm{p}=.008] ;$ and satisfaction $[\mathrm{F}(2,144)=3.404, \mathrm{p}=.036]$. This shows that teacher respondents do have differences in engagement and satisfaction about emergency remote teaching. The results also suggest that the difference in educational attainment led to differences in how teachers engage in online teaching. Due to the unprecedented shift in the conduct of conventional classes, teachers have a different perception of satisfaction, yet they are generally satisfied with what they have done and offered for the students despite coping from this sudden transition.

It was also emphasized that there are limited studies on teachers' satisfaction in a virtual setting, especially in the $\mathrm{K}$ to 12 programs [6]. Indeed, several studies on classroom engagements and satisfaction focused mainly on the learners [7-8, 20]. In effect, critical analysis of online engagements' features is not usually attended [5]. While teachers' profiles such as sex and age are 
commonly associated with respondents' perceptions and behavior, their educational attainment and specialization remain unattended. For instance, a study revealed that female teacher-candidates have a higher level of satisfaction than their male counterparts, contrary to the results of this present study. In the same paper, teacher-candidates in the 29-36 age bracket have shown a higher satisfaction in virtual instructions than those who belong to the age interval of 23-28, precisely when material usefulness is measured [18]. Teachers' engagement through different strategies must consider learners' needs to establish satisfaction and engagement in an online platform [19].

\subsection{Significant Difference between the Level of Teachers' and Students' Perceptions of Online Instructions in Terms of Engagement and Satisfaction}

\begin{tabular}{|c|c|c|c|c|c|c|}
\hline \multicolumn{7}{|c|}{ ANOVA } \\
\hline & & $\begin{array}{l}\text { Sum of } \\
\text { Squares }\end{array}$ & Df & Mean Square & $\mathrm{F}$ & Sig. \\
\hline \multirow[t]{3}{*}{ ENGAGEMENT } & Between Groups & 25.974 & 1 & 25.974 & 140.999 & .000 \\
\hline & Within Groups & 102.054 & 554 & .184 & & \\
\hline & Total & 128.028 & 555 & & & \\
\hline \multirow[t]{3}{*}{ SATISFACTION } & Between Groups & 71.832 & 1 & 71.832 & 226.984 & .000 \\
\hline & Within Groups & 175.320 & 554 & .316 & & \\
\hline & Total & 247.152 & 555 & & & \\
\hline
\end{tabular}

The study has a statistically significant difference between the teachers' and students' engagement and satisfaction on emergency remote teaching at $p<.05$. The result reveals that teacher's and student's perception on ERT: engagement $[\mathrm{F}(1,554)=140.999, \mathrm{p}=.000]$; and satisfaction $[\mathrm{F}(1,554)$ $=226.984, \mathrm{p}=.000]$, the interaction between these terms was significant. These results suggest that teacher's engagement and satisfaction with emergency remote teaching is different from how students perceive these ERT. Specifically, the results suggest that the teachers' and students' engagement in taking emergency remote teaching is different.

\section{Conclusion}

Studies on students' learning engagement and satisfaction with online instructions have been investigated, measuring different features. In contrast, teachers' engagement and satisfaction remain underexplored in research, especially in online teaching in basic education. This present study explored both teachers' and students' engagement and satisfaction during the emergency remote teaching that further proved their flexibility and motivation to achieve both pedagogical and learning success. Generally, both teacher and student respondents revealed high engagement in a new learning modality despite those challenges caused by the COVID-19 pandemic. This positive result is parallel to their high satisfaction in virtual instructions despite students' dissatisfaction with their learning, the benefits of online teaching, contents provided as instructional materials, and the school authorities' support during the sudden shift to remote instruction.

Similarly, teachers' profiles such as strand and years in service generally show their significant differences in their perception of satisfaction while age and educational attainment appear significant in their perceptions of both engagement and satisfaction. However, teacher respondents and studentrespondents show different perceptions of the measured variables. While it is claimed that studies on online instructions have dominated researchers' interests, it remains interesting to look into the 
degree and influence of the teachers in an online environment as teachers' online behavior and competence undoubtedly construct learners' engagement and satisfaction. Despite the affirmative engagement and satisfaction of the respondents during the emergency remote teaching (ERT), the results remain limited in the perspectives of the senior high school teachers and students in a premier Catholic institution. It is also interesting to emphasize that the respondents' high level of engagement and satisfaction is highly influenced by a strong Learning Management System (LMS) of the institution like other comprehensive universities in the country. It is, therefore, encourage to conduct similar studies using more comprehensive tools and methods among students of government schools. It is important to investigate further the real condition of the public school teachers and learners in their engagement and satisfaction in their virtual instructions. This recommendation will not only differentiate the condition of the private and public virtual instructions, but most important, this will serve as a reference in the furtherance of the quality of teaching and equality in learning.

\section{References}

[1] Amir, L.R., Tanti, I., Maharani, D.A., Wimardhani, Y.S., Julia, V., et al. (2020). Student perspective of classroom and distance learning during COVID-19 pandemic in the undergraduate dental study program Universitas Indonesia. BMC Medical Education, 20, 1-8. https://doi.org/10.1186/s12909-020-02312-0.

[2] [Asio, J.M.R., \& Bayucca, S.A. (2021). Spearheading education during the COVID-19 rife: Administrators' level of digital competence and schools' readiness on distance learning. Journal of Pedagogical Sociology and Psychology, 3(1), 19-26. https://doi.org/33902/JPSP.2021364728

[3] Asio, J.M.R., \& Riego de Dios, E.E. (2019). The college students' perspective on what makes an educator well-qualified. Journal of Pedagogical Research, 3(3), 126-138. http://dx.doi.org/10.33902/jpr.v3i3.124.

[4] Bolliger, D.U. \& Wasilik, O. (2009). Factors influencing faculty satisfaction with online teaching and learning in higher education. Distance Education, 30(1), 103-116. doi: 10.1080/01587910902845949.

[5] Borup, J., Graham, C. R., \& Drysdale, J. S. (2014). The nature of teacher engagement at an online high school. British Journal of Educational Technology, 45(5), 793-806. doi:10.1111/bjet.12089.

[6] Borup, J. \& Stevens, M.A. (2016). Factors influencing teacher satisfaction at an online charter school. Journal of Online Learning Research, 2(1), 3-22.

[7] Dixson, M.D. (2015). Measuring student engagement in the online course: The online student engagement scale (OSE). Online Learning, 19(4). doi 10.24059/olj.v19i4.561.

[8] Farrell, O. \& Brunton, J. (2020). A balancing act: a window into online student engagement experiences. International Journal of Educational Technology in Higher Education. 17. 10.1186/s41239-020-00199-X

[9] Ghaderizefreh, S. \& Hoover, M.L. (2018). Student satisfaction with online learning in a blended course. International Journal of Digital Society (IJDS), 9(3), 1393-1398.

[10] Hew, K.F. (2016). Promoting engagement in online courses: What strategies can we learn from three highly rated MOOCS. British Journal of Educational Technology, 47(2). doi:10.1111/bjet.12235, 320-341.

[11] Hu, M. \& Li, H. (2017). Student engagement in online learning: A review. 2107 International Symposium on Educational Technology (pp. 39-43). Doi: 10.1109/ISET.2017.17.

[12] Naxer, M. (2019, June 10). Self-determination theory and online education: A primer. Ecampus Course Development Training. Oregon State University. Retrieved from https://blogs.oregonstate.edu/inspire/2019/06/10/self-determination-theory-and-online-education-aprimer/

[13] Pazzaglia, A.M., Clements, M., Lavigne, H.J. \& Stafford, E.T. (2016). An analysis of student engagement patterns and online course outcomes in Wisconsin. (REL 2016-147). Washington, DC: U.S. Department of Education, Institute of Education Sciences, National Center for Education Evaluation and Regional Assistance, Regional Educational Laboratory Midwest. Retrieved from http://ies.ed.gov/ncee/edlabs

[14] Picciano, A. G. (2017). Theories and frameworks for online education: Seeking an integrated model. Online Learning, 21(3), 166-190.doi: 10.24059/olj.v21i3.1225.

[15] Raes, A., Vanneste, P., Pieters, M., Windey, I., Noortgate, W., et al. (2020), Learning and instruction in the hybrid virtual classroom: An investigation of students' engagement and the effect of quizzes. Computers \& Education, 143, 103682. https://doi.org/10.1016/j.compedu.2019.103682. 
[16] Roach , V. \& Lemasters, L. (2006). Satisfaction with online learning: A comparative descriptive study. Journal of Interactive Online Learning, 5(2), 317-332.

[17] Salayo, J.D., Fesalbon, J.E.R, Valerio, L.C. \& Litao, R.A. (2020). Senior high school teachers' and students' engagements during the emergency remote teaching (ERT): Perceptions on readiness, attitude, and competence. Studies in Humanities and Education, 1(1), 74-96.

[18] Sapanca, H. F. (2015). Satisfaction level of teacher candidates in online learning: Case study of Eastern Mediterranean University (Master's thesis). Available from http://irep.emu.edu.tr:8080/jspui/bitstream/11129/3253/1/sapham.pdf.

[19] Seo, K., \& Gibbons, S. (2019). Learner engagement in teacher education. Oxford Research Encyclopedia of Education. Retrieved from https://oxfordre.com/education/view/10.1093/acrefore/9780190264093.001.0001/acrefore9780190264093-e-263.

[20] Strong, R., Irby, T.L., Wynn, J.T. \& McClure, M.M. (2012). Investigating students' satisfaction with eLearning courses: The effect of learning environment and social presence. Journal of Agricultural Education, 53(3), 98-110. DOI: 10.5032/jae.2012.03098 98.

[21] Turley, C. \& Graham, C (2019). Interaction, student satisfaction, and teacher time investment in online high school courses. Journal of Online Learning Research, 5(2), 169-198.

\begin{abstract}
AUTHORS' BIOS
Juland D. Salayo teaches English and Research at the University of Santo Tomas (Senior High School) - Manila. He finished his Bachelor's degree in Secondary Education (English) and Master's in Educational Management from Southern Luzon State University (Lucban, Quezon) and Polytechnic University of Philippines, respectively. He is currently writing his dissertation for his Doctor of Philosophy in English Education degree at the Philippine Normal University-Manila. His research interests include critical language pedagogy, sociolinguistics, stylistics analysis, and language education.
\end{abstract}

Jann Ernest R. Fesalbon graduated Cum Laude from the National Center for Teaching ExcellencePhilippine Normal University-Manila Campus and received a Bachelor of Science in Chemistry for Teachers (BSCT) with a Specialization in Teaching Mathematics (CTP-MATH). In 2019, he received his graduate degree in Master of Arts in Education, major in Educational Management \& Leadership at The Royal and Pontifical University of Santo Tomas. His research interest is in social sciences, especially educational psychology, educational leadership, and curriculum \& instruction.

Lorena C. Valerio is a graduate of Political Science and Bachelor of Laws. She finished Master of Government Administration and a Doctorate in Public Administration. She is also a Licensed Professional Teacher. Currently, she is a teacher at the University of Santo Tomas. Her research interest includes local administration, constitution, educational management, and systems.

Rodrigo A. Litao is a graduate of A.B. English, M.A. English, and Ph.D. Educational Management from the University of Santo Tomas-Manila. Presently, he is an Associate Professor of USTDepartment of English, Faculty of Arts and Letters. Concurrently, he is an Associate Professional Lecturer of the UST-Graduate School (Education Cluster) and, at the same time, the Assistant Principal for Curriculum and Instructions of the University of Santo-Senior High School. His research interests include language education and curriculum and instruction. 